\title{
Corrupt Practices in Nigeria's Local government: A Critical Perspective
}

\author{
Nwaodike, ChibuzorAyodele, Ph.D \\ Department of Political Science and Public Administration, Babcock University, Ilishan-Remo, Ogun State, \\ Nigeria.
}

\begin{abstract}
Nigeria operates a federal system of government and power is allocated to federal, state and local governments. Collaborative efforts was encouraged to promote socio-economic development. Unfortunately due lack of diversification of the economy and over concentration on crude oil, it now operates a monolithiceconomy. Federal government on monthly bases share the proceed to the three levels of government but ironically, nothing significant is shown for the huge allocations due to corrupt practises by public servant. Documentary data were obtained from published books, reputable journals, government publications, magazines, newspaper publications, internet sources and personal observations. The paper observed that corrupt practices is on the increase and are manifested through the state joint local government account, non-remittance of the contributive pension scheme, non-payment of salaries and allowances, collusion in the transaction of government businesses, lack of proper accountability, denial of statutory functions, basically the revenue generating items and overbearing influence of the state government. The paper concludes that local government is at the verge of total collapse if adequate measures were not taken to savage the situation. Therefore, it recommended thatState Joint Local Government Account often regarded as Joint Allocation Account should be scrapped, and all statutory allocations to councils be credited to them directly. This demands that Section 162 (5, 6, 7 and 8) of the 1999 constitution of Nigeria as amended should be amended to guarantee direct access of the proceeds from the statutory allocations to the local governments. Again, the 5\% share of the original 20\% statutory allocation for the local governments should be preserved for the primary school teachers' salaries and allowances. Anti-corrupt agencies should extend their search light to the third tier of government, while corrupt public servants and governors who siphoned local government funds should be prosecuted during and after their term in office to serve as deterrent to others.
\end{abstract}

Keywords: Local Government, Corruption, Revenue Generating Items, Federation Account, Collusion.

\section{INTRODUCTION}

Nigeria operates a federal structure and powers are shared among the component units. This is indicative that local government is the third tier of government and is expected to be autonomous in the discharge of its duties. This was the essence of the various reforms at the grassroot governance, especially, the 1976 local government reform that among others recognised the council as a third tier of government and with powers to execute certain functions.However, after many years of experimenting with the local government system, scholars have expressed concern over the parlous state of local councils in Nigeria and the apparent disconnect between it and the lives of the people. Therefore, if anyone is to examine the reasons for Nigeria's underdevelopment and the state of the nation, one should visit the local councils (Nwaodike, 2013). Consequently, the councils have failed to deliver in its responsibilities. This non-performance can be traced to many factors such as corrupt practices, lack of local autonomy, and lack of qualified personnel/manpower among others. Most critical of these factors is corruption. Recently, there are allegations that state governments have consistently interfered on the political, financial and administrative functions of the councils and have created a master-servant relationship between the state and the local government (Nwaodike, 2013).The councils have not only becomes an appendages of the states, but the latter have also gone further to create a Joint Allocation Account Committee (JAAC) through their State Houses of Assembly to facilitate Section $162(6,7$ and 8) of the 1999 constitution as amended. This section created State Joint Local Government Account where federal/ statutory allocation between states and local governments are made. Monies statutorily allocated to the councils were alleged to have been siphoned by the chief executives of the states. This act has rendered the local government incapacitated especially in executing their assigned functions due to lack of funds. Therefore, local governments has become a shadow of themselves. The thesis of this study is to examine the implications of corrupt practices on socio-political development of the third tier of government that inhabited the larger number of the people. 


\section{CONCEPTUAL CLARIFICATION}

Corruption varies and it depends on the context at which it is used. That is, it could be moral depravity and perversion of integrity through bribery or favour, or a conscious and well planned act by a person or group of persons to appropriate by unlawful means the wealth of another individual or group. Whereas to others, it is the act of turning power and authority into ready cash. It could also be viewed as the diversion of resources from betterment of the community to the gain of individuals at the expense of the community (Aluko, 2006). Typology of corruption can be classified into various groupings. But more obvious in the society include; political, economic, administrative, organised, and working class. Political corruption is perpetrated by political office holders. This is to acquire or retain political power. This is done through vote-buying and all forms of election malpractices. Economic corruption is often perpetrated by businessmen and contractors often motivated by financial gains for themselves and in collaboration with public servants who helped them to get contract. Organised corruption is often done in large scale. Is a complex criminal activities done by groups of elite and control agents, for the primary purpose of enriching participating allies at the expense of the larger community. These include, price-fixing, hoarding, racketeering, smuggling, burglary, armed robbery and 419 scams. Working-class corruption is similar to administrative corruption. The only difference is the status of the perpetrators. These among others include, artisans, messengers, account clerks and market women. The reality is that these corrupt practices are perpetrated at the local government in Nigeria. It has become a worrisome issue because the rural dwellers and the less privileged are at the receiving end.

\section{LOCAL GOVERNMENT}

Local Government is government at the local level created to decongest the functions and burden of the other tiers of government, bring about democratic climate of opinion; provide valuable political education, provide two-way communication; and ensure even and rapid development (Nwaodike, 2013). It is usually created by a law of the State in a federal system of government and the law of the central government in a unitary state and given adequate power and autonomy to discharge the functions assigned to it.

According to the United Nations Division of Public Administration, Local Government is a political division of a nation, which is constituted by law and has substantial control of local affairs including the powers to impose taxes or exert labour for prescribed purposes. The governing body of such an entity is elected or otherwise locally selected (Okiki, 2010:3). This means that Local Government is a legally constituted body created for the grassroots level purely for developmental purpose (Bamgbose, 2011). These definitions has basic features which include elective representatives, constitutionally recognised functions and powers to recruit personnel and generate revenue so as to execute its programmes (Nwaodike, 2013). On this note, Nwaodike (2013:25) conclude that "localgovernment isa governmentat the grassrootwith powers to elect its representatives and is saddledwith responsibilityto provide social welfare of the local peoplewith relative interference from the higher authority". However, most Local Governments in Nigeria have been unable to fulfil their obligations at the grassroots due to excessive external control from the States.In this paper, local government and local councils are used interchangeably.

\section{THEORETICAL FRAMEWORK}

The paper is anchored on system theory. The theory was propounded by biologist Ludwig Von Bertalanffy in 1940's (Heylighen and Joslyn, 1992). Major thesis of this theory is that societal phenomena exist and are related, however, there are boundaries in some occasions that separate them. Each system whether political, economic, social, cultural or otherwise has characteristics such as structures, functions, actors, values, norms, goals, inputs, outputs, response and feedback. These features are affected by the ecology. On this note, a system is a set of phenomena that affect each other within an environment that transform to a larger pattern different from any of the parts. That is, whatever affect any part invariably have effect on the whole.In a State such as Nigeria, the federal, State and Local Governments are interdependent. Although their roles are differentiated, they all work towards achieving the collective goals of the State which include meeting the needs of the populace, providing infrastructure, mobilizing people and resources to meet ends amongst others. Local Governments play vital role in the development of the State especially in the developing ones, since they have the privilege of knowing and understanding the needs and resources of their domain and as such can provide better facilities to meet the demands of the population. But when these resources are denied and abuse due to corrupt practices by public office holders, the populace suffers who ordinarily should be the benefactor of good governance.

\section{TRENDS OF CORRUPT PRACTICES AND ITS IMPLICATIONS ON LOCAL GOVERNMENT ADMINISTRATION}

The 1976 local government reform listed a single tier multi-purpose local government and ever since then, Nigeria as a country has adopted this form of local government administration. The implication of the above is that a similar method of corrupt practices is obtainable virtually in all the local councils in the country (Aluko, 
2006: 55). In every state of the federation, council chairmen and other top local government officials have been accused of embezzlement, misappropriation of funds, extra-budgetary spending, purchase of official vehicles (sometimes unnecessarily) at unreasonably exorbitant prices, and outrageous expenditure on security (Newswatch, 2001:54-63). Ever since local government was recognized as a third tier of government, evidence has proven and there is no doubt about it that considerable amount of fund has been allocated to them. Paradoxically, there is little or no evidence at the various councils to show for these huge amounts of money. For instance, in the year 2004 alone, a total of N38.04 billion (the Punch, 2 June 2004: 34) as statutory allocation was disbursed to the 774 local governments in Nigeria; the question is what has really come of the huge amount? The simple answer is that it has given room for extravagant lifestyle on the part of the local council officials at the expense of the provision of essential basic socio-economic and infrastructural facilities for the local inhabitants. Before any analysis is made on some of the evidences available on corrupt practices in the local government, it is important to look at the forms of corruption at these levels of government. However, these forms of corrupt practices are a product of collusion. According to Yakubu and Oyewo (2000:165) collusion is defined as conspiracy to fraud and quoting Section 422 of the Criminal Code, they state inter alia, that: "any person who conspires with another by deceit or any fraudulent means to affect the market price of anything publicly sold, or to defraud the public, or any person, whether a particular person or not, or to extort any property from any person, is guilty of a felony.Hornby (2000:217) sees collusion as "a secret agreement, especially in order to do something dishonest or to deceive people". Whereas Aluko $(2007,33)$ defines it as "a secret or illegal activity undertaken by two or more people (or two or more groups) in a formal organization for the purpose of fraud". However, Aluko (2006:73) highlighted forms of collusion on corruption visible in the local government system. These include,

i. funding of political parties

ii. inflated contract prices or quotations

iii. collusion between external auditors and government functionaries

iv. collusion between supervisory ministries/bureau and local governmentchairmen

v. collusion with citizens who benefit from thieving public funds.

Be that as it may, evidences abound on reckless spending of local government officials through the above listed forms of collusion. For example, in Kaduna state, the chairman of Kachia local government area awarded a contract of N2.5 million for rehabilitation and completion of a women's centre but no work was done; he spent $\mathrm{N} 1,913,990.00$ on a rural electrification project, instead of the approved budget of N1, 385,540.00, the report further stated that the chairman of Sabon Gari LGA council ignored the provisions of the Financial Memorandum and gave each of his councilors N150,000.00 for loyalty; he spent N1million as touring allowance for the month of August 2000 alone; and spent another N1.5 million on radio communication equipment. The same report had it that the extra-budgetary spending of the Samga local government chairman stood at N16,495,605.70; he even awarded a contract for office rehabilitation worth N3,171,375.00 when the value of the said office rehabilitation ought to be N906,044.00(Newswatch,2001, quoted in Aluko, 2006).

In Imo State, the House of Assembly investigated the activities of the local government councils following series of petition of corrupt practices. The investigative committee of the House reported among others, that in Ekime Mbano local government Area some projects said to have been executed by the council did not exist. These acclaimed projects include the rehabilitation of the Umuezeala autonomous community road, for which payment of N172, 000 was said to have been made on 31 March, 2000. From the report, it was discovered that the road was not graded and neither was the contractor paid as claimed by the council. Beyond this, the council was also accused to have inflated the prices of vehicles purchased and repairs the sum of N950, 000 and N76, 500 respectively. More so, approval of N417, 000 for the filling of potholes with laterite at NkwoUmuezeala and Aba branch roads which the council claimed was never executed (Aluko, 2006).

Oyo state also witnessed a similar case, precisely in Ibadan North-East local government. The council chairman was suspended on 30 April, 2001, by the councilors. The speaker of the council claimed that the chairman completely overstepped the bounds of his authority when he awarded a contract for the rehabilitation of one kilometer road in Aremo for N76million. Initially, the councilors said to have advised against the project base on the fact that the road led to a cemetery and was of no commercial and special value to the community in question. Again, the chairman was reported to have spent N4million on the construction of a car park at the back of the council, to decongest the roads and make money for the council, whereas the park hardly made N100 a day. (Newswatch, 2001 quoted in Aluko, 2006).

Of course, Ogun State local government cannot claim to be free from similar corrupt cases, on June 13, 2010, Sunday Punch reported a case captioned "N30bn Fraud: EFCC Storms Ogun". In that report, former chairmen of Ikenne local government, Chief Adepegba Otemolu and Obafemi Owode local government, Mr Akeem Adesina were among the chairmen being investigated over the alleged diversion of N30bn excess crude oil allocated to the 20 local government areas of the state in 2009. 
Other forms of corrupt practices in local government are through the use of illegal staffs popularly known as "ghost workers". The number of workers on the pay roll of the council is much more than the legitimate number of workers actually working in the council. Sometimes these ghost workers are regarded as consultants, liaison officers etc. in fact, some of these names do not exist in actual sense, that is, council officials only add such fictitious names and the money meant for such ghost names will finally find their way or be transferred to these officials account. Some ghost workers in some states are illegal names given by political office holders comprising their supporters who are not working but collecting wages/salaries from the local governments (Nwaodike, 2013).Besides the aforementioned forms of corrupt practices, others come in the form of fake projects as part of the ongoing developmental projects the councils claim to have embarked on. These unidentified projects include, drainage systems, lockup shops, construction of new and renovation of the existing ones respectively, agricultural projects like poultry farms, health centers for their staffs, etc. the council normally adds these projects as part of their achievement for the year but in real sense, such hardly exist. Hence, allocations meant for the budgeted projects are distributed among the local government officials to the detriment of the local people.Improper accountability of the excess crude oil fund is another means of corruption in the local government. Normally, every tier of government is entitled to additional allocations especially when there is increase in the price of crude oil in a given month through the excess crude account. Hence, one begins to ask what happens to such polls? The simple and obvious answer is that the local government officials in conjunction or at the order of their state governors divert such funds for private use. Besides these, the councils has the habit of disbursing illegal funds to party leaders within the local government (Nwaodike, 2013).

The implication of the foregoing is that local government is acclaimed to be the center of corrupt practices, thus, a stiff mechanism is adopted by the higher level government to monitor the activities of the councils. In the process, some of their constitutional rights are infringed upon, thus, encroaching on their jurisdiction is inevitable. This is not to conclude that other tiers are exempted or exonerated from corrupt practices.Another worrisome scenario is that state governments in Nigeria often takes away some functions constitutionally meant for the local government that can generate funds for the local government councils. The issue is that some basic functions of local government have suffered the same fate especially on the revenue items that are exclusive functions of the local government. These include, construction of markets, motor-parks, signage (notice board), corporate packing by companies, mobile advert, refuge collection and clearing/sweeping of the roads. As it is obtainable in other states, Ogun State is not exempted. The mobile advert is in the residual list of the local government. For instance, 4(1k1) maintained that "control and regulation of outdoor advertising and hording". But in the state, the Otunba Gbenga Daniel led Administration sent a bill to the State House of Assembly to pass a law that the mobile advert be collected by Ogun State Signage and Advertising Agency (OGSAA) on behalf of all the councils. The initial plan was that the proceeds will be shared between the state and the local government, but the irony is that throughout the period he was the governor of the state, there was never any record suggesting that the proceeds was shared. So the local governments in the state did not benefit from the mobile advert despite the fact that the agency collected the revenue on their behalf (Nwaodike, 2013). The situation has not changed since Governor Ibikunle Amosun led government came on board.

Aside the denial and starvation of monies meant for the local governments, there are illegal and sundry deductions from Joint Allocation Account Committee by the state government. It is on record that state governments deduct primary school teachers salaries and allowances which is 'first line charges' and they do not go into the state government purse.However, there are other deductions made from the State Joint Local Government Account. The percentage may look like stipends, but it amount into millions of naira on monthly basis. These among others include:

$1.1 \%$ training fund for Local Government Service Commission.

$2.4 \%$ for the traditional rulers (traditional council).

$3.7 .5 \%$ for employer contributions (contributory pension/NCPS).

$4.5 \%$ redemption bond.

$5.15 \%$ primary school teacher' pension.

6. Maintenance of Ministry of Local Government and Chieftaincy Affairs.

7. Contribution to SUBEB.

8. $0.5 \%$ life insurance premium.

$9.1 \%$ audit fees.

$10.15 \%$ local government staff funds. As a result of the above deductions, outright scrapping of the account were considered for thefollowing reasons:

1. Inability of the local government to carry out developmental projects at the grassroot.

2. Irregular and atimes, non-payment of salaries and allowances of the local government functionaries.

3. To allow local governments to have financial and administrative autonomy.

4. To allow the existing local governments to function effectively in their duties.

5. To limit the overbearing influence from the state government. 
6. To reduce unnecessary deductions from the local government account by the state government.

7. To allow even distribution of dividends of democracy.

8. To allow the elected political officers fulfil their promises to the masses in the local government area.

9. It makes the local government to be at the mercy of the state government by going all about cap-in-hand begging for funds.

10. To put an end to illegal deductions from the local government funds.

11. To put a stop to the delay in the remittance of local government funds.

12. To put a stop to unnecessary interference in local government affairs.

13. For the harmonisation of local government funds.

Moreso, Nwaodike (2013) revealed that sometimes it has become a tradition for the local government not to pay all deductions made from workers salaries to relevant purses such as cooperative societies. The councils are starved of the federal statutory allocation and as a result of this, the local government are unable to meet the above responsibilities. Others are inability of the state government to remit check-off dues of the industrial unions in the local government areas, inability to pay leave bonuses and non remittance of $15 \%$ pension deductions in most local governments as at when due, tax deductions at source on salaries yet to be paid to local government workers and over-delay in the transfer of distributed limited allocations to the local government councils which often delay the payment of salaries and allowances of the local government workers on regular basis. More worrisome is the $100 \%$ burden of the responsibilities of the payment of primary school teacher's salaries, leave bonus, pensions and other charges on the local government. This in particular is often deducted as first line charges. While the beauty of presidential system of government are among others separation of powers and checks and balances. However, legislative arms in this level of government hardly capitalise on the doctrines to stamp their authority, especially, when the executive arm goes contrary or beyond its powers. It means that the body is not performing its legal or constitutional role. The resultant effect of this is corruption. Corrupt practices have become the bane of local government administration in Nigeria, therefore, have been canonically accommodated, entertained and celebrated within the system (Adeyemi, 2012). These legislatures (councils) demand for bribes from the executive arm in order to have his way. It could be in the process of passing a bye law, approval of budget among others. In this regard, corruption is misnomerly labelled and euphemistically referred to as "Egunje" (Lawal and Oladunjoye, 2010:232).Egunje is a slogan which means "illegal offer" in South-West Nigeria.

In the course of this, officials at the local level do not adhere to provisions of the financial memorandum (FM), conspicuous consumption on the part of the local officials, lifestyles that are not commensurate with official sources of income, imposition of leaders on the local government through corrupted political process and low wages of local government officials (Ali, 2008). The resources allotted to the councils are mismanaged. Thus, priorities are mismanaged; projects are done hap-hardly. Regrettably, this collusion is carried out in tune with selfish end and aggrandisement of the political leadership and senior bureaucrats at the local government level of administration (Adeyemi, 2012).

This scenario has negative effect on the political system. That is, democratic values are eroded. The consequences as averred by Lawal and Oladunjoye (2010: 233) include:Corruption tends to destroy democratic ethos in the local government system. All the values of democracy, such as responsiveness, accountability, participation and human development, are either subdued or neglected where corruption thrives. Secondly, development is hindered in a regime of corruption. Rather than utilising the available resources for the upliftment and development of the council, they are diverted to private use. Thirdly, rule of law is also subverted and replaced by muscle power. In order to successfully steal government resources, the officials in the local government system undermine the values and regulations that guide their activities and ensure that whatever is stolen by them cannot be traced or tracked within their tenure in office. This has serious implication for service delivery as developmental projects may be abandoned without any necessary action. Also in this ugly capacity, contracts are bound to be inflated, bribes and kickbacks are bound to be taken and contracts are also bound to be awarded to non-existent companies (i.e companies that exist on paper alone). Finally, manpower development and capacity building becomes sluggish and discouraged in the arena of corruption. The chief executive of the councils is not thinking about the need to train and re-train the staffers, but how to steal the money meant for manpower development and capacity building into his own pocket for selfish purpose. The effect of corruption in the local government councils is somehow negative in the sense that democratic values are destroyed and development at grassroot is hindered.

Beside the aforementioned, another dangerous trend as witnessed in most local governments across the federation is the non-payment of salary and entitlement to the local government employees as at when due. In fact, some ofthesestates no longer allocate the statutory allocations to the local government, while the employees are directly paid by the state government. The implication of this is that the councils are at the mercy of the state government and cannot initiate any developmental project. The employees at local government who hardly 
receive their salaries and allowances are not committed to service. Some of these employees finds it extremely difficult to feed and pay their wards school fees, while the crime rate had skyrocketed and had led to insecurity in the society.

\section{CONCLUDING REMARKS}

Corruptionis on the increase in Nigeria's local government and this were the manifestation of bad leadership at the state level and has transcended to the local government. This has affected and therefore reduced the status of the councils to mere servant and appendages of the state government. Mere visit of some of these local governments shows that little or nothing is happening in terms of developmental projects, public servants are not accountable to the people, democratic values are eroded, human, manpower and capacity building suffers, delay in payment of salaries and allowances, over burden of the councils with primary school education and insecurity become the order of the day. These socio-political underdevelopment were as result of corrupt practices at this level ofgovernment. The paper therefore, recommend that, all illegal deductions often made by the state government from the local government funds should stop. This means that State Joint Local Government Account often regarded as Joint Allocation Account should be scrapped, and all statutory allocations to councils be credited to them directly. This demands that Section $162(5,6,7$ and 8) of the 1999 constitution of Nigeria as amended should be amended to guarantee direct access of the proceeds from the statutory allocations to the local governments. Again, the 5\% share of the original $20 \%$ statutory allocation for the local governments should be preserved for the primary school teachers' salaries and allowances and be paid directly (as the first line charge) from the Federation Account through the Universal Basic Education Commission. In this regard, the fiscal allocation should be restructured to reflect this change. This will guarantee speedy payment of primary school teachers' salaries and allowances as well as promote effective and efficient primary school education. Anti-corrupt agencies should extend their search light to the third tier of government, while corrupt public servantsand governors who siphoned local government funds should be prosecuted during and after their term in office to serve as deterrent to others.

\section{REFERENCES}

[1] Adeyemi, O. O., Akindele, S. T., Aluko, O. A. and Agbesin, B. (2012)."Institutionalising the Culture of Accountability in Local Government Administration in Nigeria".

[2] African Journal of Political Science and International Relations Vol 6(4), PP. 81-91.

[3] Aluko, J. O. (2006). Corruption in the Local Government System in Nigeria. Ibadan:Oluben Printers.

[4] Aluko, J.O. (2007), The Dynamics of Local Government Administration. Abuja:Bluesland Communication Limited.

[5] Bamgbose, J. A. Traditional Institutions and Local Government in Olojede, I; Fajonyomi,B; Fatile, J. (2011).Contemporary Issues in Local Government Administration in Nigeria.LagosRakson Nigeria Ltd.

[6] Federal Government of Nigeria (FGN) (2008).1999 Constitution of the Federal Republic of Nigeria and Fundamental Human Rights (Enforcement Procedure Rules) 2008, Abuja: Government Printers.

[7] Heylighen, F. andJoslyn, C. (1992). What is Systems Theory? Principia

[8] Cybernetica. www.pespmc1.vub.ac.be/systheo.html. Retrieved July 15, 2016 at 2.57pm

[9] Hornby, A. S. (2000) ed, Oxford Advanced Learner's Dictionary of Current English, $6^{\text {th }}$ Edition. S. Wehmeier: Oxford University Press.

[10] Lawal, T. and Oladunjoye, A. (2010). "Local Government Corruption and Democracy inNigeria". Journal of Sustainable Development, Volume 12, No. 5. http://www.jsd-africa.com

[11] Nwaodike, C. A. (2013). Local Government Autonomy and Grassroot Democracy in Ogun

[12] State, Nigeria (1999-2012). A Ph.D Thesis Submitted in the Department of Political

[13] Science and Public Administration, Babcock Business School, in Fulfilment of the

[14] Requirements for the Award of the Degree of Doctor of Philosophy in Political

[15] Science, Babcock University, Ilishan-Remo, Ogun State, Nigeria.

[16] Newswatch, (2001), "Looting of Local Government". Lagos, vol.33, no 25, P.54-63.

[17] Okiki, A. (2010). "Nigerian Local Government and its Needed Autonomy". Retrieved on12/4/2015 at 8:19pm http://okikilinks.blogspot.com/2010/05/nigerian-local-government-and-its-.html

[18] Owen, B. (2012). What is Development? Center for Global Development. www.cgdev.org/blog/whatdevelopment Retrieved July 15, 2016 at $3.05 \mathrm{pm}$.

[19] Punch, (2004), "Summary of Gross Revenue Allocation by the federation Account Allocation Committee for the Month of April 2004 Shared in May 2004". Lagos. P.34

[20] Sunday Punch, (2010), "N30bn Fraud: EFCC Storms Ogun”. Lagos, June 13.

[21] Yakubu, J. A. and Oyewo, A. T. (2000), Criminal Laws and Procedure in Nigeria.Lagos: Malthouse Press. 